\author{
COMPARATIVE ANALYSIS OF CFEU AND NORTH AMERICAN \\ JURISPRUDENCE IN THE AREA OF THE VALIDITY \\ OF JURISDICTION CLAUSES IN ONLINE \\ CONSUMER CONTRACTS*
}

\title{
ANÁLISIS COMPARADO DE LA JURISPRUDENCIA DEL TJUE Y DE LOS TRIBUNALES NORTEAMERICANOS EN MATERIA DE VALIDEZ DE LAS CLÁUSULAS DE ELEGGIÓN DE TRIBUNAL EN LOS GONTRATOS DE CONSUMO ONLINE
}

\author{
Juan M. VELÁZQUEZ GARDETA**
}

ABSTRACT: Consumer relations concluded by Internet represent a challenge to jurists, who in the area of offline contracts are forced to rethink many issues that had already been settled. One of the most crucial of these issues is the validity of jurisdiction clauses. Added to the debate on self-regulation and state control is the factor of the traditional lack of protection of consumers and the speed with which contracts are concluded on the net. The possibility of the consumer bringing an action in the state in which they live is the key to making the principle of effective legal protection a reality. Regulation of the formal criteria for jurisdiction clauses and the establishment of underlying principles not only guarantee balance between the sides but also foster increased confidence in online consumer relations.

The experience of the north American courts in question, derived from the large numbers of online transactions, are exportable to other legal systems.
RESUMEN: Las relaciones de consumo que se verifican por Internet suponen un reto para los juristas, que se ven obligados a repensar muchas cuestiones ya pacíficas para el ámbito de los contratos online. Una de las más trascendentes es la validez de las cláusulas de elección de tribunal competente. $\mathrm{Al}$ debate entre autorregulación y control estatal se suma el factor de la tradicional desprotección de los consumidores y la velocidad de celebración de contratos en la red. La posibilidad de que el consumidor interponga su demanda en el Estado de su domicilio es la clave para que el principio de tutela judicial efectiva sea real. La regulación de los criterios formales de las cláusulas de elección de tribunal y el establecimiento de unos principios de fondo no sólo garantizan el equilibrio entre las partes, sino que van en

* Artículo recibido el 6 de enero de 2016 y aceptado para su publicación el 21 de junio de 2016.

** Profesor agregado de derecho internacional privado en la Universidad del País Vasco/Euskal Herriko Unibertsitatea. Grupo de investigación consolidado del Gobierno Vasco IT 759-13.

Boletín Mexicano de Derecho Comparado nueva serie, año XLX, núm. 148 , enero-abril de 2017, pp. 427-456.

D. R. (C) 2017. UNAM, Instituto de Investigaciones Jurídicas. 
Esta revista forma parte del acervo de la Biblioteca Jurídica Virtual del Instituto de Investigaciones Jurídicas de la UNAM www.juridicas.unam.mx

DOI: http://dx.doi.org/10.22201/iij.24484873e.2017.148.11006

Some concepts like those of stream of commerce or doing business which are related to active and passive websites still form the basis for drawing up rules for international judicial competence. In this respect the European Union has the advantage that it is an integrated system with a supreme body to interpret law. Finally, the need for conventional rules is clear in America, where attempts at unification have been fruitless.

Keyzeords: international judicial competence, consumer contracts, internet, jurisdictional clausesfreedom of choice, comparative law. pos de un aumento de la confianza en las relaciones de consumo online.

La experiencia de los tribunales norteamericanos en la cuestión, derivada del mayor número de transacciones online, sirve para ser exportada a otros sistemas jurídicos. Algunos conceptos como el de stream of commerce o doing business, que guardan relación con sitios web activos y pasivos, son la base aún de la elaboración de normas de competencia judicial internacional. En ese sentido, la Unión Europea cuenta con la ventaja de ser un sistema integrado con un máximo órgano intérprete del derecho. Por último, la necesidad de normas convencionales se hace patente en América, donde los intentos de unificación han sido estériles.

Palabras clave: competencia judicial internacional, contratos de consumo, internet, cláusulas de elección de foro, autonomía de la voluntad, derecho comparado.

SUMMARY: I. Introduction. By way of a preliminary explanation of the scope of the issue. II. Online consumer protection in North American jurisprudence. III. Protection within the sphere of the European Union. IV. Other examples of consumer protection in the sphere of the Americas. V. Final considerations.

\section{INTRODUCTION. BY WAY OF A PRELIMINARY EXPLANATION OF THE SCOPE OF THE ISSUE}

The reason for devoting this paper solely to consumer relations verified online lies first of all in the figures ${ }^{1}$ showing that the Internet, as well as being an obvious internationalising factor because of the ease of communication

\footnotetext{
1 If a current world population of a little over 7,260 million inhabitants is taken as a starting point, with around 3,270 million users, this represents a penetration rate of $45 \%$ and an increase in the period 2000-2015 of 806\%. See http://internetworldstats.com/stats.htm (consulted on 9th October 2015)
}

D. R. (C) 2017. UNAM, Instituto de Investigaciones Jurídicas, Boletin Mexicano de Derecho Comparado, núm. 148, pp. 427-456. 
Esta revista forma parte del acervo de la Biblioteca Jurídica Virtual del Instituto de Investigaciones Jurídicas de la UNAM

it provides, is a sphere where consumption is growing extraordinarily fast. This means that new problems are arising linked - not only in consumer protection - to the enormous variety and richness that make it necessary to reconsider whether solutions established for the analogue sphere are also valid for the online context. The debate between regulation by states and self-regulation on the net will rage for a long time when faced with any attempt by national systems to lay down criteria restricting the freedom of operation of Internet users. ${ }^{2}$

I have set a second limit with a view to the adjective 'international' itself, which leads me to concentrate only on the issue determined primarily by international private law rather than national material law. This does not set out to be a comparative law study of the consumer protection mechanisms in force in each national legal system, but concentrates on the clauses determining judicial competence (jurisdiction clauses) in cases of contractual interpretation or controversy arising from the contract.

However, it is true that it would be limiting not to take North American jurisprudence as a point of reference, even though it is circumscribed to internal purposes rather than to strictly international ones. The first reason for this is the plethora of cases and the abundance of decisions that exist there, because of widespread access to the Internet and online commerce. ${ }^{3}$ These decisions will serve as an example in issues like the validity of agreements on choice of court or arbitrator included in a contract and to show the lack of a single criterion across the courts of the different states of which the USA is made up.

Finally, some reference should be made to other areas. In this respect, the jurisprudence of the Canadian Supreme Court is illustrative of a change of course in the issue of jurisdiction clauses if the two most sig-

2 Two extreme positions serve as a sample. On one side, in favour of liberalisation, see Barlow, J. P., "A Declaration of the Independence of Cyberspace", https://projects.eff. org/ barlow/Declaration-Final.html (consulted in November 2015). On the other, in favour of state regulation, Johnson, D. / Post D.G., "Law and Borders - the Rise of Law in Cyberspace", Stanford Law Review, 47, Stanford, 1996, pp. 1367-1402.

3 Nearly 280 million Internet users in a population of 321 million inhabitants, with a penetration rate of $87.4 \%$. See http://internetworldstats.com/stats. htm (consulted on 9th October 2015). With regard to online commerce in the USA, this is expected to reach a turnover of 320,000 million dollars by 2015 , accounting for around $7 \%$ of the country's total retail trade. See http://wrwr.census.gov/retail/index.html.

D. R. (C) 2017. UNAM, Instituto de Investigaciones Jurídicas, Boletín Mexicano de Derecho Comparado, núm. 148, pp. 427-456. 
Esta revista forma parte del acervo de la Biblioteca Jurídica Virtual del Instituto de Investigaciones Jurídicas de la UNAM

nificant decisions of recent times are compared: Dell Computer v. Union des consommateurs and Seidel v. Telus communications.

Mention will also be made, if only in passing, of the situation in the rest of the Americas, with some examples of international private law, and in particular the unsuccessful - but brilliant - project for a legal agreement applicable to some international consumer contracts and transactions presented by Brazil at CIDIP VII.

The intention is that this overview should serve as a brief analysis of the current state of consumer protection, paying special attention to contracts made on the Internet but extrapolating conclusions to the analogue sphere.

\section{ONLINE GONSUMER PROTEGTION IN NORTH AMERICAN JURISPRUDENCE}

One of the first contributions of the country's jurisprudence to the question of judicial competence in respect of controversies arising from consumer contracts, along with the obligation to abide by the jurisdiction clause included in the contracts, is the "stream of commerce" theory and criteria to determine when a website is active or passive (the "sliding scale test"), originally established in the Zippo v. Zippo decision. It is well-known that in this decision the consumer's attitude when entering into a contract and the possibilities offered by the website are determined, so that in cases where the offer is aimed at the consumer's state, the latter cannot be deprived of the protection of the jurisdiction of the said state in which they reside.

Though this decision has been questioned recently, the principles of interpretation proposed in it have also inspired the jurisprudence of the Court of Justice of the European Union (CJEU), as will be seen below.

Among the voices in American jurisprudence that disagree with the formula proposed in Zippo $v$. Zippo to measure the interactivity of a website, one might highlight Howard v. Missouri Bone, ${ }^{5}$ though it has to be said that this decision does not distance itself very far from the fundamental premises of the proposal in Zippo v. Zippo.

\footnotetext{
4 Zippo Manufacturing Co v. Zippo Dot Com, Inc., 952 F. Supp. 119 (E. D. Penn. Jan. 16, 1997).

5 Howard v. Missouri Bone and Foin Center, Inc., 2007 WL 1217855 (Ill. App. $5^{\text {th }}$ Dist. April 24, 2007).

D. R. (C) 2017. UNAM, Instituto de Investigaciones Jurídicas, Boletin Mexicano de Derecho Comparado, núm. 148, pp. 427-456.
} 
Esta revista forma parte del acervo de la Biblioteca Jurídica Virtual del Instituto de Investigaciones Jurídicas de la UNAM

There have also been discrepancies with the theory proposed in Zippo v. Zippo in a series of recent cases concerning verified online auctions, specifically those using the eBay platform. The most recent of these include Sayeedi v. Walser, ${ }^{6}$ Dudnikov v. Chalk $\mathcal{E}^{9}$ Vermilion; ${ }^{7}$ Boschetto v. Hansing ${ }^{8}$ and Attaway v. Omega. ${ }^{9}$ However, it does not so much question the method proposed to determine the level of interactivity of a website - and therefore the possibility of establishing the competence of the courts in the defendant's state of residence - as its suitability to be applied to the triangular relationships that exist on an online auction platform (specifically, in Sayeedi $v$. Walser, the following was said:

Under the Zippo sliding scale test, proper exercise of personal jurisdiction in a claim involving Internet contact is directly proportional to the commercial interactivity of the website over which the contact is made. However, this mode of analysis makes little sense in the eBay context since eBay, and not the user, controls the interactivity and marketing efforts of the website.

6 Masood H. Sayeedi v. Timothy D. Walser, Civil Court of the City of New York, Richmond County 2007 N. Y. Misc. LEXIS 497 (February 27, 2007).

7 K. Dudnikov, and M. Meadors v. Chalk \& Vermilion Fine Arts, Inc., a Delaware corporation, and Sevenarts, Ltd., a British Corporation, District Court of the District of Colorado (D. C. No. 05-cv-02505-WDM-MEH).

8 P. Boschetto v. F.D. Hansing et al., District Court of the Northern District of California, no. CV-06-01390-VRW.

$9 \quad$ R. Attaway and M. Attaway v. Llexcyiss Omega and D. Dale York, Indiana Court of Appeals, no. 11A01-0712-GV-608.

On this question see Velázquez Gardeta, J. M., "La protección del consumidor en el marco de las relaciones internacionales de consumo online. Un estudio del derecho comparado desde la jurisprudencia más reciente", Cursos de derecho internacional y relaciones internacionales de Vitoria-Gasteiz 2013, Cizur Mayor, Thomson Reuters-Aranzadi, 2014, pp. 533-562, specifically pp. 553-554. On North American doctrine, concerning the superseding of the doctrine established in Zippo $v$. Zippo for criteria for assessing the interactivity of a website, see Hunt R. J. / Karns, J. E. / Mawer, W. T., "Achieving Personal Jurisdiction Using Internet Contacts: The Need to Establish A Unified Standard", Southern Law Fournal, 2008, vol. 18, pp. 139-161; Haynes, A. W., "The Short Arm Of The Law: Simplifying Personal Jurisdiction Over Virtually Present Defendants", U. Miami Law Rev., vol. 64, 2009, pp. 133-174; Swetnam-Burland, D. / Sitham, S. O., "Back to the Future: revisiting Zippo in Light of "Modern Concerns", f. Marshall 7. Computer \& Info. L., vol. 29, 2012, pp. 231-250 and Rojao, C. "Buy It Now: Establishing Personal Jurisdiction Over Out-OfState Defendants Who Conduct Business Through Online Intermediaries", Seton Hall Law Review, vol. 43, 2013, pp. 1075-1104.

D. R. (C) 2017. UNAM, Instituto de Investigaciones Jurídicas, Boletín Mexicano de Derecho Comparado, núm. 148, pp. 427-456. 
Esta revista forma parte del acervo de la Biblioteca Jurídica Virtual del Instituto de Investigaciones Jurídicas de la UNAM

At this point it would be appropriate to divide up and categorise decisions between those that raise formal questions about the contract and those that focus on underlying circumstances that lead the court to change what is established in the contract on the principle of benefit to the consumer or because a particular clause has a manifestly unfair result.

\section{Formal problems arising from the peculiarities of entering into contracts online}

Clickwrap clauses (for a definition, see Specht v. Netscape) ${ }^{10}$ and browsewrap agreements ${ }^{11}$ form part of a very widespread system of operation and do not always offer sufficient guarantees for informed consent to all the contractual commitments.

In principle the acceptance of these formulas for consenting to conclude a contract does not raise problems, though they are not explicitly provided for in most systems. In this respect, and referring specifically to submission to arbitration, the UNCITRAL recommendation of 7th July $2006^{12}$ establishes two criteria for construing art. II.2 of the New York Convention of 10th June 2008 on the recognition and execution of foreign arbitration decisions. This precept establishes an obligation for all sides to sign a written agreement to submit to arbitration to settle their differences (a contract or commitment signed by the parties or contained in an exchange of notes or telegrams). The UNCITRAL recommendation establishes that this article should be applied while recognising that the circumstances it describes are not exhaustive.

A very different matter is determining whether these formulas for agreement, while specific in some cases, are insufficiently clear to presume that the contracting party/consumer/user has voluntarily agreed to all the terms to which they are committing themselves or has in fact done so in ignorance (due to error or bad faith on the part of the supplier).

10 Specht v. Netscape Communications Corp., 2001 WL 755396 S. D. N. Y.

11 Rodríguez de las Heras Ballell, T., "Las condiciones de uso de los sitios web y los browse-wrap agreements", DeCITA. Derecho del comercio internacional. Temas y actualidades, 5/6. 2006, pp. 43-73, specifically pp. 49 and 50.

12 Recommendation concerning the construal of paragraph 2) of article II and paragraph 1) of article VII of the New York Convention of 10th June 1958, adopted by the United Nations Commission for the Unification of International Trade Law on 7th July 2006 in its 39th session, A/61/17.

D. R. (C) 2017. UNAM, Instituto de Investigaciones Jurídicas, Boletin Mexicano de Derecho Comparado, núm. 148, pp. 427-456. 
Esta revista forma parte del acervo de la Biblioteca Jurídica Virtual del Instituto de Investigaciones Jurídicas de la UNAM

Below are some recent examples of jurisprudential decisions (in the USA and Canada) motivated-among other arguments-by consumers' claims of having difficulty accessing all the contractual clauses, there being no need to read the commitments before agreeing to them or the placing of some of the contractual commitments on other web pages.

Worth emphasising-because of the many questions related to online contracts discussed in it-is the decision by the Cour Suprême de Canada in Dell v. Union des consommateurs. ${ }^{13}$ Contradicting decisions handed down at the first instance and at appeal, the court did not consider it to be relevant that the jurisdiction clause (based in the United States), included in the pre-formulated standard contract presented by the Dell company to its customers had to be accessed via an external link (hyperlink) leading to the website of the arbitration entity designated as competent in the contract. Moreover, unlike the lower courts, neither was importance attached to the fact that this clause was written in smaller characters than the rest of the contract and located at the bottom of the page, all for the confessed purpose of not distracting the user's attention from the main subject, in short the purchase of the product. For these and other reasons the court considered the jurisdiction clause binding on both sides and did not allow the claimants to go to Canadian courts, so contradicting the criteria upheld by the courts of first instance and appeal. ${ }^{14}$

In the subsequent De fohn v. The TV Corporation, ${ }^{15}$ the court, faced with the argument asking the contract to be declared null and void because of ambiguity in the clause, took a very similar position ("These claims fail because DeJohn had an opportunity to review the terms of the Register. com Agreement by clicking on the hyperlink Register.com provided. The fact that DeJohn claims that he did not read the contract is irrelevant because absent fraud (not alleged here) failure to read a contract is not a get out of jail free card").

13 Dell Computer Corp. v. Union des consommateurs et Olivier Dumoulin, 13th July 2007 (2007 CSC 349).

14 However, the criteria applied in this decision have been superseded by the recent decision handed down by the Canadian Cour Suprème in the case of Seidel v. TELUS Communications Inc., (2011SCG 15), though this crucial decision affects the underlying issue of clauses choosing arbitrators rather than formal questions.

15 Decision by the Northern District of Illinois of 16th January 2003 [245 F. Supp. 2d 913 (C.D. Ill. 2003)]. 
Esta revista forma parte del acervo de la Biblioteca Jurídica Virtual del Instituto de Investigaciones Jurídicas de la UNAM www.juridicas.unam. $\mathrm{mx}$

DOI: http://dx.doi.org/10.22201/iij.24484873e.2017.148.11006

Decisions in other cases maintain a similar position. In B. G. Forrest v. Verizon Communications Inc., ${ }^{16}$ the court ruled that the consumer making the claim was being adequately informed of the choice of court even though the pertinent clause was in a place where reading it all at once was impossible, the only option being to read it in part in a scroll box, even though the designated competent court was located in the supplier's state. In Net2Phone, Inc. v. The Superior Court of Los Angeles, ${ }^{17}$ it was considered as a habitual practice in Internet contracts for the terms of the contract - like the jurisdiction clauses - only to be available via hyperlink and this way of informing consumers about the competent court was considered not unfair, before going into other underlying arguments. ${ }^{18}$ The opinion of the court handed down in the case D. Hubbert v. Dell, ${ }^{19}$ is revealing in the matter of small print in online contracts ("Although there is not conspicuousness requirement, the hyperlink's contrasting blue type makes it conspicuous. Common sense dictates that because the plaintiffs were purchasing computers online, they were not novices when using computers. A person using a computer quickly learns that more information is available by clicking on a blue hyperlink").

There are two decisions that contradict this. First is that handed down in Specht v. Netscape Communications Corp.,${ }^{20}$ where the court considered that consumers could not be bound by the jurisdiction clause as they were not adequately informed of it. The reason was that to download the program they did not have to agree explicitly to any clause ("browsewrap agree-

16805 A. 2d. 1007 (Dist. of Columbia Court of Appeals, Aug. 29, 2002).

17108 Cal. App. 4th. 583 (Cal. Crt. App., June 9, 2003).

18 In this regard see the decision by the CJEU of 21st May 2015, Case C-322/14, Jaouad El Majdoub v. CarsOnTheWeb GmbH, where it was considered sufficient for electronic transmission to fulfil the same functions as writing as it provides a lasting record of the choice of court clause in the sense required by art. 25.1 a) of Regulation 1215/2012 - it is sufficient for the information to be stored and printed before entering into the contract. See comments by Orehudo Prieto de los Mozos, P., "Cláusulas de sumisión en contratos electrónicos internacionales: eficacia del click wrapping”, La Ley 4709/2015.

In a recent decision by the New York state court of appeal in the case Starkey v. G. Adventures, Inc., F.3d, 2015 WL 4664237 (2nd Cir. August 7, 2015) considered the jurisdiction clause obligatory among the general contract conditions accessed via hyperlink, including in email sent by the travel agency to the consumer making the claim.

19359 Ill. App. 3d 976, 835 N.E. 2d 113 (Ill. App. 5 Dist., Aug. 12, 2005).

20 Heard initially by the New York district judge (2001 WL 755396 S. D. N. Y.), whose opinion was borne out at appeal in October 2002 [306 F. 3d 17, 26 n. 11 (2d Cir. 2002)].

D. R. (C) 2017. UNAM, Instituto de Investigaciones Jurídicas, Boletin Mexicano de Derecho Comparado, núm. 148, pp. 427-456. 
Esta revista forma parte del acervo de la Biblioteca Jurídica Virtual del Instituto de Investigaciones Jurídicas de la UNAM

ment"), but the supplier nevertheless considered it issued by the simple fact of downloading as it was printed at the foot of the web page, though it was not necessary to read to the bottom of it to download the program, which was also free.

In M. Defontes and $\mathcal{N}$. Long v. Dell Computers Corp. et al., ${ }^{21}$ it was established that the submission to arbitration clause was deliberately placed at the bottom of the supplier's web page (from which the order had to be made) and this location was not ideal for consumers to be properly informed of the conditions under which they were entering into a contract.

Finally, an unpublished decision $-M$. Cohn v. Truebeginnings ${ }^{22}$ the grounds in fact of which, as well as being unusual but which, on the other hand, the court agreed to hear, ${ }^{23}$ stand out because online consumers are treated in a different way from offline consumers, assuming they have a higher level of information and requiring from them greater diligence in accepting contractual clauses designating the competent law and court.

Alongside these decisions - which are not entirely consistent between one another - about the information given to consumers online and the formal circumstances in which they receive it, it should be pointed out that it is widely believed that the vast majority of consumers (online and offline) tend not to read clauses in contracts. ${ }^{24}$

\section{Striking down the jurisdiction clause according to the criterion} of benefit to the consumer

Within a context of absolute implementation of pre-formulated standard clauses (especially those specifying a court or arbitrator), there is contradictory jurisprudence on this question. On the one hand, decisions can be found that allow the consumer to make a claim before a forum more favourable to him or her (because it involves cheaper, more conve-

\footnotetext{
21 Of 29th January 2004, 2004 WL 253560 (R. I. Super. CT. 2004).

22 California Appeal Court. B190423 (Los Angeles County Super. Ct. No. BC344082).

23 The claimant considered that the online contact company discriminated against men in relation to women by offering the latter free long-term contracts while the former were only given one or two weeks' free subscription to the service.

24 Hillman, R.A., "On-line Consumer Standard-Form Contracting Practices: A Survey and Discussions of Legal Implications", Corner Law School-Legal Studies Research Paper Series, Paper 29, 2005, http://lsr.nellco.org/cornell/lsrp/papers/29.
} 
Esta revista forma parte del acervo de la Biblioteca Jurídica Virtual del Instituto de Investigaciones Jurídicas de la UNAM

nient litigation in terms of travel, etc., or because legislation in the state in question has specific regulations in the are of small claims or class action or similar benefits). On the other hand, there are decisions that, while appreciating the benefits to the consumer of litigating in a specific court, impose obedience to the contractual clause.

The former group includes a large number of decisions. Thus, in Dix v. $I C T^{25}$ the court allowed the consumer claimants to lodge a claim with the courts in their state (Washington), despite the contractual jurisdiction clause specifying the supplier's state (Virginia) because legislation in the latter did not allow class actions. As the claims by each of the consumers were for small amounts, forcing them to abide by the jurisdiction clause would have meant a lack of legal protection, and consequently infringed a fundamental public policy of the state, which is punishable under the pertinent law, the Consumer Protection Act. In the case of America Online v. Pasiek ${ }^{26}$ the court ruled on the basis of similar arguments. Also similar are the legal decisions in Aral v. Earthlink ${ }^{27}$ and C. Comb v. Paypal, ${ }^{28}$ though in both cases what the court allowed was to ignore the jurisdiction clause by going to ordinary courts because the former option would implicitly involve renouncing the taking of class actions. The former offered an interesting line of reasoning not to apply the law of the state of Georgia, as the contract stipulated, but which would have meant obligatory submission to arbitration and no possibility of any class action. The court found sufficient objective grounds for applying this applicable jurisdiction clause but considered that California had a greater material interest than Georgia in the matter and therefore ruled that the law of California should apply, prioritising the possibility of bringing class actions in processes of this kind over any other consideration.

In the same way, Williams v. America Online ${ }^{29}$ Licitra v. Gateway ${ }^{30}$ and Scarcella $v$. America Online ${ }^{31}$ stand out for favouring access by consum-

25 S. Dix and F. Smith v. ICT Group, Inc. and America Online Inc., no. 77101-4, 2007 WL 2003407 (Wash. July, 2007).

26 No. 1D03-2290, 2004 Fla. App. Lexis 764 (Jan. 29, 2004).

272005 WL 3164648 (Cal. Ct. App. 2d Dist., Div., 4 Nov. 29, 2005).

28218 F. Supp. 2D 1165 (N.D. Cal. Aug. 10, 2007).

292001 WL 135825 (Mass. Super., February 8, 2001).

30734 N. Y. S. 2d 389 (Civil Court of the city of New York, Richmond County, October 18, 2001).

31 No. 570315/05, 2005 WL 3542868 (N.Y. App.Term., Dec. 28, 2005).

D. R. (C) 2017. UNAM, Instituto de Investigaciones Jurídicas,

Boletin Mexicano de Derecho Comparado, núm. 148, pp. 427-456. 
Esta revista forma parte del acervo de la Biblioteca Jurídica Virtual del Instituto de Investigaciones Jurídicas de la UNAM

ers - in view of the small size of their claims - to the courts of the states in which they are resident whatever other stipulations may be contained in the contract. In the latter, moreover, the fact of the limit - higher or lower - set by legislation in each state for access to small claims courts was highlighted as a factor where consumers' interests take priority over the stipulations of the contract.

On the other hand, different opinions are stated in the above-mentioned Dell v. Union des consommateurs, Net2phone v. The Superior Court of Los Angeles County and D. Hubbert v. Dell and also - giving priority to the contractual agreement over the possibility of class action - there are Caspi v. Microsoft $t^{32}$ and Groff v. America Online. ${ }^{33}$

Arguments are even to be found - in line with these jurisprudential decisions - that tie up with the theory of economic analysis of law, like the recent case of $H$. and S. Meier v. Midwest Recreational Clearinghouse. ${ }^{34}$ This decision, arising from the purchase of a defective vehicle on an online auction platform, deals with the difference in criteria between the consumer claimants who want to lodge a claim before the courts of their home state (California) and the wish of the defendant company to enforce the jurisdiction clause imposed in the contract, which submits the case to the courts of the company's home state (Minnesota). The courts took the position established in the seminal decision - radically opposed to the interests of consumers - handed down by the Supreme Court in Carnival Cruise Lines v. Shute, ${ }^{35}$ where it is argued that suppliers presumably translate the benefit provided by clauses stipulating a nearby jurisdiction into a lower price, so that consumers benefit in terms of cost. The court - in an exaggerated presumption of good faith on the part of suppliers - ended by stating that there is no evidence that the inclusion of clauses stipulating a jurisdiction close to the supplier represent an attempt to dissuade consumers from making claims.

Finally, this ignores the theory established in Zippo v. Zippo concerning passive and active consumers and the stream of commerce in stating that the supplier's website is accessible from anywhere in the world, which

\footnotetext{
32732 A. 2d 528 (N. J. App. Div., July 2, 1999).

331998 WL 307001 (R. I. Superior Ct., May 27).

34 Hans Meier and Susan Meier v. Midwest Recreational Clearinghouse, LLC, and DOES 1 through 20, inclusive, Eastern District Court of California, no. 2:10-cv-01026-MCE-GGH.

35499 U.S. 585 (1991).
} 
Esta revista forma parte del acervo de la Biblioteca Jurídica Virtual del Instituto de Investigaciones Jurídicas de la UNAM

means that if the jurisdiction clause in the contract were not upheld the supplier could face a multitude of potential jurisdictions.

\section{Striking down certain standard contractual clauses because they are unfair to consumers (procedurally and substantively unconscionable)}

North American courts have resolved the controversy over abusive clauses by applying criteria of disproportionality or unfairness because of the imbalance between the two sides and the one-sided nature of the obligations arising from them. This is on the basis that it is a question of preformulated standard clauses with no real negotiation between the sides (a take or leave it basis).

The main defect in this formula, which could be a good solution to balance the position of consumers, is that it relies on jurisprudential criteria, which means that decisions can be based on widely differing criteria. Thus, there are decisions rejecting a particular standard clause that stipulates submission to a certain court, arbitrator or applicable law as being unfair to consumers, as in the above-mentioned C. Comb v. Paypal, Aral v. Earthlink, Bragg v. Linden, Defontes v. Dell, Mazur v. eBay or others such as Oestreicher $v$. Alienware. ${ }^{36}$ In these decisions it is established that the waiver by consumers in the respective standard online contracts of the possibility of bringing class actions, small claims actions or proceedings through the jurisdiction of their place of residence places them in an unconscionable position of imbalance. To take just one example, the decision of the court in Aral v. Earthlink: "Although Aral did not allege fraud, the gravamen of the complaint is that numerous consumers were cheated out of small sums of money through deliberate behaviour. Accepting these allegations as true, as we must at this stage of the proceedings, the class action waiver must be deemed unconscionable under California law".

It is true that these positions came about as a consequence of attempts by certain consumers to bring a claim before a court that would be more favourable to them, against the resulting opposition of the supplier who drew up the contract. On other words, they represent neither a general rule nor the result of an action as a matter of course by judicial bodies. Proof of this are the decisions in the opposite sense, like the above-

\footnotetext{
362007 WL 2302490 (N. D. Cal. Aug. 10, 2007).
} 
Esta revista forma parte del acervo de la Biblioteca Jurídica Virtual del Instituto de Investigaciones Jurídicas de la UNAM

mentioned Dell v. Union des consommateurs and D. Hubbert v. Dell. The former considered a waiver of class actions admissible ("malgré son importante portée sociale, n'est qu'un véhicule procedural dont l'emploi ne modifie ni ne crée des droits substantiels"), even in the case of entering into a standard contract ("Cela ne signifie que l'adhérent ne peut pas consentir véritablement au contrat et être lié par chacune de ses clauses, même si certaines d'entre elles pourraient être nulles ou sans effet par l'application de quelque autre disposition de la loi").

In any case this is an excessively arbitrary solution to the difficult challenge of compensating for the exercise of false free will in online consumer contracts.

\section{PROtection WITHIN THE SPHERE OF THE EUROPEAN UNION}

The new Regulation (EU) no. 1215/2012 on jurisdiction and the recognition and enforcement of judgments ${ }^{37}$ represents progress in several respects in the elimination of formalities in enforcing foreign court decisions within the EU. This regulation takes up the mandate of arts. 67.4 and 81.2 a) of the Treaty on the Functioning of the European Union (TFEU) to adopt measures in accordance with ordinary legislative procedure to guarantee mutual recognition between member states of court and other judgements, as well as their enforcement. ${ }^{38}$

While on the one hand it is true that the declaration of enforceability is no longer required before a foreign court judgement can be enforced, appeals against enforcement are still allowed in a logical effort to preserve the right of defence. ${ }^{39} \mathrm{In}$ short, it is a manifestation of the tension between the principle of due process of law and the mutual recognition of court decisions, on the one hand, and the guarantee of rights of defence as set forth in the Krombach ${ }^{40}$ decisions, among others.

\footnotetext{
37 DO no. L 351, of 20th December 2012.

38 Art. 81.2 a) TFEU.

39 See Rodríguez Vázquez, M. A., "Una nueva fórmula para la supresión del exequátur en la reforma del reglamento Bruselas I", Cuadernos de Derecho Transnacional, March 2014, vol. 6, no. 1, pp. 330-347, especially pp. 337-340.

40 CJEU judgement of 28th March 2000, case C-7/98, Dieter Krombach / André Bamberski, Rec. 2000, p. 01935. Also CJEU (1st court) decision of 14th December 2006, case
} 
Esta revista forma parte del acervo de la Biblioteca Jurídica Virtual del Instituto de Investigaciones Jurídicas de la UNAM www.juridicas.unam. $\mathrm{mx}$

DOI: http://dx.doi.org/10.22201/iij.24484873e.2017.148.11006

In the area of regulating international jurisdiction, the ambition expressed in the initial drafts ${ }^{41}$ was notably reduced with regard to the application of the regulations to cases where the defendant is not domiciled in a member state. As regards consumers, the new art. 18.1 provides grounds for the competence of the legal organs of a member state, regardless of whether the defendant (seller or service provider) is domiciled in a member state or has an agency, branch or establishment in one.

With regard to the specific regulation of competent jurisdictions in the field of contracts concluded by consumers (arts. 17-19) - except for the change mentioned in the previous paragraph - it does not differ from what is laid down in Regulation 44/2001. ${ }^{42}$

This regulation, in terms of protecting the consumer as the weaker side in the relationship, concentrates on making it possible to act against the defendant both before the courts of their domicile and before those of the claimant, but actions can only be brought against them before the courts of the member state in which they are domiciled (art. 18). Jurisdiction clauses that contravene these provisions are null and void (art. 19) unless they meet certain conditions, in order to avoid the clauses of the type included in the vast majority of consumer contracts where the consumer's free will cannot be exercised.

It should not be forgotten that this protection is reserved for the passive consumer, one who receives an offer in the member state in which they live rather than travelling to consume or consuming during a trip to

G-283/05, ASML Netherlands BV v. Semiconductor Industry Services GmbH (SEMIS), Rec. 2006, p. I-12041 and CJEU (main court) decision of 28th April 2009, case C-420/07, Meletis Apostolides v. D.C. Orams and L.E. Orams, Rec. 2009, p. I-03571.

See also Velázquez Gardeta, J. M. "La indefensión del demandado como excepción en el proceso civil internacional dentro de la Unión Europea", in Goizueta, J. \& Cienfuegos, M. (eds.), La eficacia de los derechos fundamentales de la UE. Cuestiones avanzadas, Cizur Mayor, Thomson Reuters-Aranzadi, 2014, pp. 215-246.

41 See Campuzano Díaz, B., "Las normas de competencia judicial internacional del reglamento 1215/2012 y los demandados domiciliados fuera de la UE: análisis de la reforma / The Rules of Jurisdiction in Regulation 1215/2012 and Defendants Domiciled Outside the European Union: Analysis of the Reform", Revista Electrónica de Estudios Internacionales, DOI: 10.17103/reei.28.08.

42 Regulation (EC) No. 44/2001 of the Council, of 22nd December 200, on jurisdiction and the recognition and enforcement of judgments in civil and commercial matters, DO no. L 012, of 16th January 2001.

D. R. (C) 2017. UNAM, Instituto de Investigaciones Jurídicas, Boletin Mexicano de Derecho Comparado, núm. 148, pp. 427-456. 
Esta revista forma parte del acervo de la Biblioteca Jurídica Virtual del Instituto de Investigaciones Jurídicas de la UNAM

another country. In the latter cases the rules for jurisdiction are the same as for any other contract.

There is no specific provision for the case of consumer contracts made via Internet, nor did any such provision exist in the previous regulations. It is true that the most recent consumer protection rules explicitly include contracts concluded at a distance by electronic means for the purposes of subjecting them to the same formal requirements as other contracts or in other questions such as the right of withdrawal. This is the case with Directive 2011/83 on consumer rights. ${ }^{43}$ They also fall within the scope of application of Directive 93/13 on unfair terms in consumer contracts $^{44}$ even though when it came into force e-commerce did not exist. In any case, GJEU doctrine as expressed in the Mostaza Claro ${ }^{45}$ and Asturcom $^{46}$ cases would be perfectly applicable to a consumer contract concluded via Internet for the purposes of considering invalid a jurisdiction clause contained in a contract concluded between a vendor and a consumer on the grounds that it was unfair.

However, where the closest attention has been paid to the specific issue of consumer protection online as regards the validity of jurisdiction clauses is in CJEU jurisprudence. Analysis of this gives a valid criterion for determining whether specific regulation is necessary in the field of international jurisdiction or whether the jurisprudential parameters of this court have in fact left things sufficiently clear.

\section{Pammer/Hotel Alpenhof}

In the first case of the two included in the judgement, Mr. Pammer, resident in Austria, lodged a claim against a travel agency domiciled in Germany before the Austrian courts. Prior to this, Mr. Pammer had, through an intermediary company, arranged a voyage on a cargo ship from Trieste to the far east on conditions that in his opinion were not met

43 DO L 304/64, of 22nd November 2011. Repeals Directive 97/7 on the protection of consumers in respect of distance contracts.

44 DO L 95, of 21st April 1993.

45 GJEU judgement of 26th October 2006, case C-168/05, Elisa Maria Mostaza Claro v. Centro Móvil Milenium, Rec. 2006-I, p. 10421.

46 CJEU judgement of 6th October 2009, case C-40/08, Asturcom Telecomunicaciones, S.L. v. Cristina Rodríguez Nogueira, Rec. 2009- I, p. 09579.

D. R. (C) 2017. UNAM, Instituto de Investigaciones Jurídicas, Boletín Mexicano de Derecho Comparado, núm. 148, pp. 427-456. 
Esta revista forma parte del acervo de la Biblioteca Jurídica Virtual del Instituto de Investigaciones Jurídicas de la UNAM

on the means of transport, ${ }^{47}$ so that he refused to embark. In his claim, Mr. Pammer applied for a refund of the sums advanced plus interest. The Austrian court that heard the appeal (Oberster Gerichtshof) formulated the following question to the CJEU: If an intermediary's website can be accessed via Internet, is this sufficient to meet the criterion that the business is "directed" (to the member state where the consumer is domiciled) in the sense of article 15, section 1, letter c), of Regulation 44/2001?

In the second case, the claimant resident in Germany used the Hotel Alpenhof website to book several rooms for a one-week stay. The booking and the pertinent confirmation were verified by email as shown on the website. The client stated he was unsatisfied with the hotel's services and left without paying even though the management offered him a discount. Consequently, a claim was lodged against the said client before the Austrian courts for the sum of 5,000 euros. Following the corresponding exclusion due to lack of jurisdiction, on appeal the case reached the Oberster Gerichtshof, which sent the same request for a preliminary ruling to the CJEU as in the case quoted above.

In its decision ${ }^{48}$ the CJEU cites a series of points of evidence - though not an exhaustive list - that can constitute presumptions that the seller's business is being directed at the member state where the consumer is domiciled, with verification of this evidence being the job of the judge in the state in question. These are: the international nature of the business, the description of itineraries from member states other than that in which the seller is domiciled, the use of a language or currency other than those habitually used in the member state where the seller is domiciled, with the option of confirming bookings in this language, expenditure on a service redirecting to websites on the Internet in order to facilitate access to the seller's site or that of their intermediary for consumers domiciled in other member states, the use of a top-level domain name other than that of the member state in which the seller is domiciled and

47 The intermediary claimed on its website that the vessel had a sports room, swimming pool, lounge, access to video and television. Also offered were three double cabins with shower and WC, a separate living room equipped with armchairs, desk, carpet and refrigerator, as well as stops to visit cities.

48 CJEU judgement of 7th December 2010, joined cases C-585/08 and C-144/09, Peter Pammer v. Reederei Karl Schlüter GmbH \& Co KG / Hotel Alpenhof GesmbH v. Oliver Heller, Rec. 2010 I, p. 12527.

D. R. (C) 2017. UNAM, Instituto de Investigaciones Jurídicas, Boletin Mexicano de Derecho Comparado, núm. 148, pp. 427-456. 
Esta revista forma parte del acervo de la Biblioteca Jurídica Virtual del Instituto de Investigaciones Jurídicas de la UNAM

the mention of an international clientele made up of customers domiciled in different member states.

Though late in relation to other jurisdictions compared here, this decision for the first time lays down a framework of solutions making it possible to presume when a consumer can be considered to be protected for the purposes of enabling litigation always to take place before the courts of their home state. ${ }^{49}$

The court's solution ignores as irrelevant whether the website is interactive, $i$. e. the mere fact of it being possible to access a website in the member state where the consumer is domiciled is not sufficient to state that a business is directed at the said state. It must be assessed on a case by case basis whether the supplier of goods and services is directing their business at the specific state where the consumer is domiciled and to do this the evidence mentioned above must be taken into account. The difference between active and passive websites is therefore no longer so decisive: as the Advocate General ${ }^{50}$ recalls, directed business can exist both from interactive and from static sites. Moreover, the latter can display more determining evidence than the former of wishing to attract customers in a specific state. ${ }^{51}$

The decision does not incorporate the criterion of commercial business carried on in the past with consumers from other member states, $i$. $e$. a kind of historical criterion to verify the supplier's business in other member states, so that a series of contracts made with other consumers in other states gives an idea of the frequency and intention in this respect. It seems reasonable that a single contract with a single consumer, together with other evidence as mentioned above may be sufficient.

The decision takes up the "old" concept, imported from north American judicial culture, of the stream of commerce, ${ }^{52}$ whose relevance for the

49 Not all doctrine is of the same opinion, see L. D'Avout, "Internet. Accesibilité ou focalisation: la Cour de Justice tranche mais ne convainc pas", La Semaine Juridique - édition générale, 2011, no. 5, pp. 226-229.

50 See conclusions of the Advocate General, Ms. Verica Trstenjak, Rec. 2010 I, p. 12527 .

51 See De Miguel Asensio, P., "El asunto Pammer y el art. 15 RBI", http://pedrodemi guelasensio.blogspot.com.es/2010/12/el-asunto-pammer-y-el-articulo-15-rbi.html.

52 See among others Castellanos Ruiz, E., "El concepto de actividad profesional 'dirigida' al Estado miembro del consumidor: stream-of-commerce", Cuadernos de Derecho Transnacional, October 2012, vol. 4, no. 2, pp. 70-92 and Lafuente Sánchez, R., "El criterio del 
Esta revista forma parte del acervo de la Biblioteca Jurídica Virtual del Instituto de Investigaciones Jurídicas de la UNAM www.juridicas.unam.mx

purposes of defending the right to a personal jurisdiction for a specific consumer has been diminished over time.

In short, the GJEU does not seem to have been wrong in its evidencebased formula for determining when a supplier is directing their business towards the member state where a consumer is domiciled and therefore affording the said consumer a higher level of protection in determining the international jurisdiction of the courts in the state where they live. The CJEU in any case makes clear that it is not sufficient for a consumer to be able to access a contractor's website to be able to affirm that its business is aimed at a state in the sense of art. $15.1 \mathrm{c}$ ) of the Brussels I Regulation (now replaced by the Brussels I bis Regulation). ${ }^{53}$

\section{Mühlleitner}

A further case between a consumer resident in Austria and a supplier with their commercial establishment in Germany was still awaiting a decision when the CJEU gave its Pammer / Hotel Alpenhof $f^{34}$ ruling.

In this case, Ms. Mühlleitner, resident in Austria, searched for a German-manufactured vehicle on the Internet with a view to purchasing it for private use. After making a selection using a website, according to her search criteria, her request was forwarded to the firm Autohaus Yusufi GbR, based in Hamburg and run by the Yusufi brothers, which offered vehicles for sale. After an initial contact by telephone (the company telephone number included an international code) in which she was guaranteed that her status as an Austrian national was no obstacle to buying the vehicle, the consumer travelled to Germany and through a contract of sale purchased a car from the Yusufi brothers for 11,500 euros, which she paid immediate-

International Stream-of Commerce y los foros de competencia en materia de contratos electrónicos celebrados con consumidores", Cuadernos de Derecho Transnacional, October 2012, vol. 4, no. 2, pp. 177-201.

53 In short, this response contains a lot of common sense, like that which leads some authors to state that otherwise, simply by a consumer clicking to accept an offer, this could bring a supplier before a jurisdiction they could not foresee. See Jayme, E., "Le droit international privé du nouveau millénaire: la protection de la personne humaine face à la globalisation", Récueil des Cours, vol. 282, 2000, pp. 9-40, especially pp. 25-30.

54 However, some leading members of Spanish doctrine consider that this decision does not add anything new to Pammer-Alpenhof. See Álvarez González, S., Comment in REDI, 2013.1, pp. 211-214.

D. R. (C) 2017. UNAM, Instituto de Investigaciones Jurídicas, Boletin Mexicano de Derecho Comparado, núm. 148, pp. 427-456. 
Esta revista forma parte del acervo de la Biblioteca Jurídica Virtual del Instituto de Investigaciones Jurídicas de la UNAM

ly. After returning to Austria she found that the vehicle she had purchased suffered from major defects and demanded that these be repaired. When the sellers refused she proceeded to lodge a claim before the jurisdictional body in her place of residence, applying for cancellation of the contract of sale she claimed to have concluded as a consumer. Following the corresponding exclusion due to lack of jurisdiction lodged by the defendants, who considered that proceedings should be heard by German courts, arguing among other reasons that the claimant/consumer had concluded the contract at the domicile of the company, which did not aim its activities at Austria, on appeal the case reached the Oberster Gerichtshof. This body posed the following question to the CJEU: Does the application of article 15, section 1, letter c) of the Brussels I Regulation require that the contract between consumer and vendor have been concluded at a distance?

The requirement for entering into the contract at a distance or, which comes to the same thing, that the consumer who travels to consume does not have the procedural protection of always being able to litigate before their own courts, was set down in the 1968 Brussels Convention, ${ }^{55}$ predecessor of Regulation 44/2001 and the current Regulation 1215/2012. This requirement has disappeared from current rules but not clearly enough for national courts not to request a preliminary ruling.

Moreover, the Pammer / Hotel Alpenhof judgement discussed above leaves room for doubt in its recitals 86 and 87 . Thus, one of the arguments used by the claimant (Hotel Alpenhof) for not applying art. 15.1.c) of regulation 44/2001 was that the contract with the consumer was concluded in situ and not at a distance as the keys to the rooms were handed over and the payment made in situ. The court did not consider this fact relevant but upheld the application of the precept as the fact is that the booking and confirmation were effected at a distance, so that the consumer concluded the contract at a distance, ${ }^{56}$ The court could therefore give the impression that it was attaching decisive importance to this requirement for entering into the contract at a distance for the purposes of affording procedural protection to the consumer.

551968 Brussels Convention on jurisdiction and the enforcement of judgments in civil and commercial matters (consolidated version), DO no. C 027 of 26/01/1998, p. $0001-0027$.

Art. 13.3. b) the consumer took the steps necessary for the conclusion of the contract in that state (the state where they are domiciled).

56 See comment by Quiñones Escámez, A., REDI, 2010, pp. 255-258. 
Esta revista forma parte del acervo de la Biblioteca Jurídica Virtual del Instituto de Investigaciones Jurídicas de la UNAM www.juridicas.unam.mx

DOI: http://dx.doi.org/10.22201/iij.24484873e.2017.148.11006

However, adding this requirement — provided for in the previous regulations of the 1968 Brussels Convention and subsequently abolishedwould mean not fulfilling the primary purpose of this precept, protecting the weaker party in the legal relationship of consumption. It is true that this requirement is mentioned in the Joint Declaration of the Council and Commission on articles 15 and 73 of Regulation $44 / 2001^{57}$ and also in recital twenty-four of the Rome I Regulation, ${ }^{58}$ but as Advocate General Trstenjak rightly points out (recital 55), this requirement poses problems with different types of contract in which the consumer can only book hotel or tourist services at a distance and then conclude the contract in the place where they use the services. Language courses and health or cosmetic treatment could also be added to this list under certain circumstances.

IN any case, it should be recalled that the expansion of the concept of a consumer contract beyond the letter of Regulation 44/2001 had already been put into practice by the CJEU in the Ilsinger case. ${ }^{59}$ Faced with a false offer of a prize which led to a claim by the addressee the question was raised of whether a consumer contract exists in such cases. ${ }^{60}$ The court considered that for the privileged jurisdiction of consumer contracts to

57 Unpublished. Can be read - among other places - at AAVV, Legislación básica de derecho internacional privado, 24th updated ed., Madrid, Tecnos, pp. 100 and 101, note 9.

58 Regulation (EG) No. 593/2008 of the European Parliament and Council, of 17th June 2008, on the law applicable to contractual obligations (Rome I), DO L 177, of 4th July 2008.

59 CJEU judgement (First Chamber) of 14th May 2009, Renate Ilsinger/Martin Dreschers, administrator in the insolvency of Schlank $\mathbb{E}$ Schick GmbH, G-180/06, Rec. 2009, p. I-3961. In recital 59 the court established, "It is therefore appropriate to consider that article 15, section one, letter c), of Regulation no. 44/2001, in its current wording, is not applicable to a court action like that at issue in the principal litigation, as the vendor did not undertake contractually to pay the prize money promised to the consumer and which the latter is now claiming. In a case like this one, the said provision is only applicable to the said action if the misleading promise of a prize was followed by a mail order contract concluded by the consumer with the company consisting of an order for goods from the latter."

60 "Does the right of consumers recognised by article $5 \mathrm{j}$ of the... «KSchG»... to claim from companies the prize apparently won when they send (or have sent) certain promises to give a prize or other similar communications to a consumer, the formulation of which can (or could) give the consumer the impression that they have won a certain prize - without making obtaining the prize dependent on ordering goods or making a single trial order where no such order is placed and the prize is claimed by the addressee of the notification, constitute, under Regulation... no. 44/2001 ..., a right in respect of contracts or equivalent, in the sense of article 15, section 1, letter c), [of the said] Regulation...?".

D. R. (C) 2017. UNAM, Instituto de Investigaciones Jurídicas,

Boletin Mexicano de Derecho Comparado, núm. 148, pp. 427-456. 
Esta revista forma parte del acervo de la Biblioteca Jurídica Virtual del Instituto de Investigaciones Jurídicas de la UNAM

apply, there must obviously be a contract and the mere offer of a prize is not sufficient. However, the court, breaking with previous jurisprudence that - in application of the said precept - attached importance to the object of the contract and limited its application to consumer contracts of a synallagmatic nature, declared that the exclusion of unilateral consumer contracts was unfounded.

The court finally settled the question in Mühlleitner when it established that both making contact at a distance, as was the case with the claimant in the main proceedings, and booking a good or service at a distance or, a fortiori, concluding a consumer contract at a distance, are evidence of a binding contract for the said business. ${ }^{61}$

\section{Emrek}

In this case ${ }^{62}$ the CJEU went a step further in its attempt to profile the requirements of art. 15.1. c) of Regulation 44/2001 (now 17.1.c) of Regulation 1215/2012). The question is posed to the CJEU of whether it is necessary for there to be a causal relationship between the vendor's website and the conclusion of the contract with the consumer.

The facts of the matter are, in summary, that Mr. Emrek, resident in Saarbrücken (Germany), purchased a used vehicle from the company run by Mr. Sabranovic in Spicheren (France). The vendor had an active website which mentioned the address of his company, including the French telephone numbers and a German mobile telephone number, together with the respective international codes. The metropolitan areas of the two municipalities are inter-related in such a way that, despite belonging to different states, their residents co-exist in a practically shared space, there being urban continuity which at some points ignores the border between the two countries.

61 However, further doubts remain and more requests for preliminary judgements will certainly be made to the GJEU on the subject of online shopping. For some of them, see R. Lafuente Sánchez, "Aplicación del régimen especial de protección de los consumidores previsto en el Reglamento Bruselas I a los contratos celebrados entre presentes. A propósito de la sentencia del TJUE de 6 de septiembre de 2012, asunto C-190/11, Mühlleitner", La Ley, núm. 7966, sección Tribuna, 16th November 2012.

62 CJEU judgement of 17th October 2013, Lokman Emrek v. Vlado Sabramovic, case C-218/12, Rec. 2013. 
Esta revista forma parte del acervo de la Biblioteca Jurídica Virtual del Instituto de Investigaciones Jurídicas de la UNAM

Due to a problem with the warranty on the vehicle, Mr. Emrek lodged a claim against Mr. Sabranovic before the German court. This court declared that it could not hear the claim due to a lack of international jurisdiction as it considered that the defendant had not directed his business at the state in which the claimant was domiciled.

After this decision was appealed against at a higher court, the Amtsgericht Saarbrücken made a request for a preliminary judgement from the CJEU: Does article 15, section 1, letter c) of Regulation no. 44/2001 demand as an additional unwritten requirement in cases where a trader's website meets the criterion for "directed" business that the consumer was induced by the website run by the trader to conclude the contract, so that the website has a causal relationship with the conclusion of the contract?

It was already made clear in the Pammer/Hotel Alpenhof judgement that the mere accessibility of the Internet is not sufficient in itself to determine that the business is aimed at a specific member state. Other factors such as the content of the website must be taken into account and related to yet other criteria that help to objectively identify the specific addressees of the offer.

The advocate general in the Emrek case, Pedro Cruz Villalón, made his opinion clear when he stated that art. 15.1.c) cannot form the basis for a requirement that a causal relationship exist between the offer aimed at the consumer's state and the decision by the consumer to conclude a specific contract (recital 21). This causal requirement would also pose undoubted problems of proof, which would fall on the consumer and often leave him or her without the protection that should be afforded by Regulation 44/2001 (as well as the current Regulation 1215/2012). However, the advocate general argues that the said causal relationship might be qualified evidence that there has been business directed at the state where the consumer is domiciled (recital 26). This conclusion is founded on elementary common sense: if there has been business directed at another member state, it is logical for this causal relationship to have come about.

The advocate general considers that, in the Emrek case - even in the absence of a distance contract and pre-contractual activity - there may be grounds to conclude that there was an offer directed at the state where 
Esta revista forma parte del acervo de la Biblioteca Jurídica Virtual del Instituto de Investigaciones Jurídicas de la UNAM

the consumer is domiciled and these involve application of the privileged jurisdiction provide for in arts. 15 et seq.

The said grounds would in this case be the geographical location in which the commercial relations took place. Mr. Sabranovic's business is in a French municipality within a metropolitan area closely linked to the city of Saarbrücken. It would seem logical that if a vendor directs an offer to one of these municipalities this would also be equivalent to making it available to the inhabitants of the other municipality as they form what is known as a conurbation. Thus, the offer would also be directed at the inhabitants of the municipality in the other member state. It does not seem - in the opinion of the advocate general - an excessive risk for sellers that claims could be made against them in the courts of the neighbouring state. It seems, however, that the question is again being posed to the CJEU in relation to circumstances where the element of confusion of the buyer's and seller's municipalities not being in the same geographical area does not arise. In this case the causal relationship between the advertisement and the conclusion of the contract, and the interactivity of web pages, will arise again and recourse to the geographical location of supplier and consumer will not be effective. ${ }^{63}$

In fact, this matter is based once more on the "old" approach to the jurisprudence of the above-mentioned Zippo v. Zippo and Howard v. Missouri Bone cases. It is a question of finally proving through evidence that business has been directed at the consumer's state (“...«doing business» means conducting business in Illinois of such a character and to such an extent that may be inferred that the defendant has subjected itself to the jurisdiction and laws of this state and is bound to appear when properly served"). ${ }^{64}$

This sentence by the Illinois Appellate Court is interesting because it settles the question of jurisdiction for a claim by a consumer against a medical service provider whose products they found out about on the Internet. The two parties resided in neighbouring states (Missouri and

63 See Velázquez Gardeta, J. M., "La protección del consumidor en el marco de las relaciones internacionales...", op. cit, p. 554; Pazos Castro, R. ,"El contrato celebrado en el marco de una actividad comercial dirigida al consumidor. Comments on the CJEU judgement of 17th October 2013 (case C-218/12, Emrek)", Boletín del Ministerio de Justicia, núm. 2165, April 2014, p.13. wrerr. Mjusticia.es/bmj.

64 Howard v. Missouri Bone, p. 5.

D. R. (C) 2017. UNAM, Instituto de Investigaciones Jurídicas, Boletín Mexicano de Derecho Comparado, núm. 148, pp. 427-456. 
Esta revista forma parte del acervo de la Biblioteca Jurídica Virtual del Instituto de Investigaciones Jurídicas de la UNAM

Illinois respectively). A similar question to Emrek was raised here, $i$. e. the consumer found out about the service thanks to the directed business of the supplier and it sets out to clarify this situation for the purposes of forcing the claimant into the defendant's jurisdiction. The latter maintains a website accessible from Illinois (the consumer's state) on which an appointment with the defendant can be requested. The defendant had also previously advertised their services by sending leaflets to high schools and other educational centres in the said state. Finally, it was proven that the defendant gave a presentation in a city in the state of Illinois.

The court considered that the level of interactivity of a website is irrelevant. In its opinion the claimant chose to contact the defendant and travel to the latter's state to receive the rehabilitation services offered. The decision differentiated between promotional actions taking place in the claimant's state and the services themselves, that are in fact provided only in the defendant's state. For all these reasons the court considered it unjustified to submit the defendant to the courts of the consumer claimant's state of residence.

It therefore does not share the criteria followed by the GJUE in Emrek. This disparity in reasoning is of no further relevance because they are different national jurisdictions, but it illustrates the possibility of future divergences and gives the impression that there is no single response in this area and in the future there may be decisions by the GJEU in the future that qualify those mentioned above.

In short, what these decisions seek is a useful list of points of evidence that the online supplier must take into account if they wish to avoid claims being lodged against them in the member state of the consumer in question. ${ }^{65}$ In any case, once the product has been posted on the network it seems to be increasingly complicated to avoid this; it may be necessary to wait for CJEU jurisprudence to consider that in some circumstances the business has not been directed at the consumer's domicile and that the competent jurisdiction must in fact be that of the supplier - as defendant - in order to assess the evidence that has led the court to reach this conclusion.

65 See De Miguel Asensio, P., "Sitios web y 'riesgo jurisdiccional' en la contratación de consumo", http://pedrodemiguelasensio.blogspot.com.es/2013/10/sitios-web-y-riesgo-jurisdiccionalen.html

D. R. (C) 2017. UNAM, Instituto de Investigaciones Jurídicas,

Boletin Mexicano de Derecho Comparado, núm. 148, pp. 427-456. 
Esta revista forma parte del acervo de la Biblioteca Jurídica Virtual del Instituto de Investigaciones Jurídicas de la UNAM www.juridicas.unam. $\mathrm{mx}$

DOI: http://dx.doi.org/10.22201/iij.24484873e.2017.148.11006

\section{Maletic}

The case of Maletic v. Lastminute $v$. TUI ${ }^{66}$ raises the requirement for the contract to be international in nature or, to put it another way, the scope of application of the jurisdiction to protect the consumer under Regulation 44/2001.

The litigation arose as a consequence of a booking for a holiday package made by the claimants (Mr. and Mrs. Maletic), resident in Bludesch (Austria), on the website of the intermediary lastminute.com, resident in Germany. The organiser of the holiday was the TUI company, based in Vienna (Austria). The booking was confirmed by the intermediary, which issued the pertinent invoice although on the details of the holiday a different hotel was shown from that in the booking. The claimants did not notice the error until they arrived at the destination, where they paid a supplement of 1,036 euros to be able to stay in the hotel they originally booked. In order to recover this supplement and in compensation for the inconvenience they had suffered on their holiday, the claimants lodged a claim with the courts of their area of residence (Blumenz, Austria), jointly, against both the intermediary lastminute. com and against the organiser TUI. The Austrian court did not accept the claim due to lack of jurisdiction over the organiser as Regulation 44/2001 is only applicable to international litigation and therefore would serve to determine jurisdiction in the case of the claim against the intermediary. In the case of the claim against the organiser of the holiday - in the view of the court - the competent jurisdictional body would be the court in the claimant's domicile, i. e. Vienna, not Blumenz.

Following the pertinent appeal by the claimants, the Austrian court decided to suspend the proceedings and put the following request for a preliminary judgement to the CJEU: must article 16, section 1 of Regulation $n^{\circ} 44 / 2001$ (now art. 18 of Regulation 1215/2012) be construed as attributing jurisdiction to the place in which the consumer is domiciled, in the sense that when the other contractual party (in the case at issue a travel agent domiciled abroad) has recourse to a co-contractor (in this case a tour operator domiciled in the same country), the aforesaid article also

66 CJEU judgement (Sala Octava) of 14th November 2013, Armin Maletic, Marianne Maletic v. lastminute.com GmbH, tui Österreich GmbH, C-478/12, Rec. 2013.

D. R. (C) 2017. UNAM, Instituto de Investigaciones Jurídicas, Boletín Mexicano de Derecho Comparado, núm. 148, pp. 427-456. 
Esta revista forma parte del acervo de la Biblioteca Jurídica Virtual del Instituto de Investigaciones Jurídicas de la UNAM

applies to the co-contractor domiciled in the same country as the actions lodged against both?

The response of the CJEU was affirmative, allowing a claim - in application of the consumer's jurisdiction - against both companies through the courts of the consumer's home state

Justification could be found rather in material criteria of protection of the weaker party and a certain logic of taking the inter-related contracts together before the same jurisdiction than in merely formal criteria or a strict interpretation of regulatory precepts.

That is to say, the basis of the decision lies in protecting the consumer as the weaker party in the contract and in reducing to the maximum the possibility of parallel proceedings to avoid irreconcilable decisions being handed down in two member states (recital 30).

If requirements of a more technical or formal nature are sought, the CJEU had already made clear that for the Brussels Convention to apply it was not necessary at all for the domiciles of the parties to be located in different member states. ${ }^{67}$

The domicile of the supplier of goods and services under consumer contracts loses further importance with the current rules of Regulation $1215 / 2012$, as in art. 18.1 it allows claims in the jurisdiction of the consumer's state against vendors based in non-EU states. There could be said to be a certain logic in this trend in the distribution of international jurisdiction as referred to in some parts of doctrine. ${ }^{68}$

\section{OTHER EXAMPLES OF CONSUMER PROTECTION IN THE SPHERE OF THE AMERICAS}

It is perhaps irresistible to refer finally, if only briefly, ${ }^{69}$ to the more ambitious effort represented by the Brazilian project for the law applicable to

67 See the CJEU judgement of 1st March 2005, Owusu, C-281/02, Rec. 2005, pp. I-383.

68 See Paredes Pérez, J. I., "La internacionalidad del contrato de consumo en el Reglamento de Bruselas I, Comentario a la STJUE del 14 de noviembre de 2013, Asunto C-478/2012, Maletic lastminute.com GmbH', La ley Unión Europea, no. 17, 2014.

69 For a more extensive study, see Velázquez Gardeta, Juan Manuel, La protección al consumidor online en el derecho internacional privado interamericano, Asunción, CEDEP, 2009.

D. R. (C) 2017. UNAM, Instituto de Investigaciones Jurídicas, Boletin Mexicano de Derecho Comparado, núm. 148, pp. 427-456. 
Esta revista forma parte del acervo de la Biblioteca Jurídica Virtual del Instituto de Investigaciones Jurídicas de la UNAM

certain international consumer contracts, which was presented at CIDIP VII but which finally did not come to fruition.

Such a convention would have represented a major step forward in terms of legal certainty in transactions of this kind in the region as it provided clarity and conciseness in its terms and in the separate concepts it included.

The convention started out by applying the law that was the most favourable to the consumer, establishing a set of presumptions between the law of the consumer's home state, that of the shared domicile of the consumer and one of the supplier's establishments and the place where the contract was concluded or executed if this coincided with the domicile or establishment of the supplier.

This protection was reserved for the passive consumer - one who does not travel to consume - leaving a wider margin for autonomy of decision in cases of active consumers.

This project was the best-structured of all those presented at CIDIP VII, and with the inclusion of clauses to determine jurisdiction in the style of those featured in Regulation 1215/2012 would have provided an unsurpassable tool for the future.

Some countries, like the Dominican Republic, have recently passed new international private law measures ${ }^{70}$ which include consumer protection measures in the area of choosing a court (art. 16.4) and applicable law (art. 63) which seem to be inspired by Regulation 1215/2012 (EU) and Regulation 593/2008 (EU).

Art. 95 of the law of 8th May 2014 adopting the Panama international private law code ${ }^{71}$ which suffers from rather unclear wording, ${ }^{72}$ also seems to opt for the jurisdiction and law that are most favourable to the consumer, over and above those stipulated in the consumer contract in question.

70 Dominican Republic International Private Law Act, Law no. 544-14 of 15th October 2014 (Gaceta Oficial de la república Dominicana of 18th December 2014).

71 Gaceta Oficial Digital of 8th May 2014

72 The final paragraph seems to invite confusion between applicable law and competent court. "At the consumer's discretion, he or she may have recourse to the jurisdiction of their domicile, that where the contract was concluded or whichever is most favourable to them, according to the principle of the prevailing interest of the consumer. The most favourable law is taken to mean the law on remedy and protection that is most appropriate to the consumer's interest". 
Esta revista forma parte del acervo de la Biblioteca Jurídica Virtual del Instituto de Investigaciones Jurídicas de la UNAM www.juridicas.unam.mx

Finally, Title IV of Book VI of the new civil code of the Argentine Republic $^{73}$ refers, for its part, to the rules of international private law. In art. 2651 it excludes consumer contracts from the scope of free will in choosing the law applicable to such contracts. This regulation is complemented by arts. 2654 and 2655, which refer to international jurisdiction and the law applicable to consumer contracts. It provides comprehensive regulations that interestingly, and unlike most of the states whose laws are compared here, it does not differentiate for jurisdiction purposes between active and passive websites, though it does distinguish in the case of applicable law ("a. if the conclusion of the contract was preceded by an offer or advertising run in the consumer's home state and the consumer took the actions necessary to conclude the contract in this state. b. if the supplier took the order in the consumer's home state. c. if the consumer was induced by their supplier to travel to a foreign state for the purposes of placing their order").

\section{FINAL GONSIDERATIONS}

One of the most crucial issues of the protection of consumers is the validity of jurisdiction clauses, specially in the case of the online relations. The usual trend of providers of goods and services in the web is to include choice of court agreements that consumers can't negotiate. So, this fact taken into account, we can say that neither the choice of law nor the choice of jurisdiction does not exist.

But, the possibility of the consumer bringing an action in the state in which they live is the key to making the principle of effective legal protection a reality. The problem is that there is not a wold wide jurisdiction and the approaches of the national courts sometimes are different.

The experience of the United Estates courts is very rich, derived from the large numbers of online transactions, and it should be taken as a valuable reference in order to obtain a fair model of regulation of the international consumer relations (online and offline). However there is not a uniform approach and we can find a contradictory jurisprudence on this question.

73 Passed by Law 26.994, which can be consulted at http://wrere.infojus.gob.ar/nuevocodigo-civil-y-comercial-de-la-nacion.

D. R. (C) 2017. UNAM, Instituto de Investigaciones Jurídicas,

Boletin Mexicano de Derecho Comparado, núm. 148, pp. 427-456. 
Esta revista forma parte del acervo de la Biblioteca Jurídica Virtual del Instituto de Investigaciones Jurídicas de la UNAM

In the European Union courts we can't find such a rich experience but the CJEU avoids the possibility of contradictory decisions. The examples of Pammer/Hotel Alpenhoff, Mühleitner, Emrek and Maletic are very clear in this regard. Pammer establishes criteria for make the crucial difference between active and passive website. The GJEU makes clear that it is not sufficient for a consumer to be able to access a contractor's website to be able to affirm that its business is aimed at a state. The decision takes up the concept, imported from North American judicial culture of the stream of commerce, adapting it to the EU reality.

In Mühleitner, the CJUE answers to the question of the Austrian court that the requirement for entering into the contract or, which comes to the same thing, that the consumer who travels to consume is not able to litigate before their own courts, has definitely dissapear.

Emrek and Maletic are two good examples of the GJEU approach in order to consolidate the protection of consumers. In Emrek the CJEU went a step further in its attempt to profile the requirements of art. $15.1 \mathrm{c}$ ) of Regulation 44/2001. The CJEU does not consider that a causal relationship between the vendor's website and the conclusion of the contract with the consumer is necessary. In this case we can detect a disparity of reasoning with the approach of the Illinois Court in Missouri Bones.

Finally, Maletic raises the requirement for the contract to be international or, to put in another way, the scope of application of the jurisdiction to protect the consumer under Regulation 44/2001.

Justification of the response of the GJEU could be found in the fact that the domicile of the supplier of goods and services under consumer contracts loses further importance, as in art. 18.1 of regulation 1215/2012 allows claims in the jurisdiction of the consumer's state against vendors based in non-EU states.

In short, the scenario is increasingly tending to avoid the scope for free will in consumer contracts, preferring jurisdictions close to the consumer.

This is absolutely clear in the case law of the GJEU and no so evident in the approach of the USA courts. The reason could be found obviously in the difference between the two judiciary systems.

However, there is an outstanding need for a convention in some geographical areas as it has been proven that areas of integration offer a higher level of security to the weaker party in a contractual relationship. 
Specially when one court - CJEU - has the ultimate interpretation monopoly of the EU's law.

Such a large scope convention - and a court with such a competences - would also represent a way of unifying principles in view of the digital and commercial gap with the neighbouring states to the north, which are more than remiss in unifying principles that would involve ceding jurisdictional and legislative sovereignty. 